\title{
MONUMENT PROTECTION: INTERNAL AND EXTERNAL PRICE EFFECTS
}

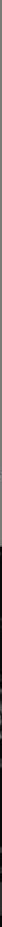


Hamburg Contemporary Economic Discussions

University of Hamburg

Faculty Economics and Social Science

Chair for Economic Policy

Von-Melle-Park 5

D-20146 Hamburg | Germany

Tel $+494042838-4622$

$\mathrm{Fax}+494042838-6251$

http://www.uni-hamburg.de/economicpolicy/

Editor: Wolfgang Maennig

P. Gabriel M. Ahlfeldt

University of Hamburg

Faculty Economics and Social Science

Chair for Economic Policy

Von-Melle-Park 5

D-20146 Hamburg | Germany

Tel $+494042838-5569$

Fax +494042838 - 6251

ahlfeldt@econ.uni-hamburg.de

Wolfgang Maennig

University of Hamburg

Faculty Economics and Social Science

Chair for Economic Policy

Von-Melle-Park 5

D-20146 Hamburg | Germany

Tel $+494042838-4622$

Fax $+494042838-6251$

maennig@econ.uni-hamburg.de

ISSN 1865 - 2441 (Print)

ISSN 1865 - 7133 (Online)

ISBN 978 - 3 - 940369 - 48 - 2 (Print)

ISBN 978 - 3 - 940369 - 49 - 9 (Online) 


\title{
Monument Protection: Internal and External Price Effects*
}

\begin{abstract}
This paper analyses the impact of heritage-listed buildings on condominium transaction prices in Berlin, Germany. We use transaction data to test for price differentials between listed and nonlisted properties and to study their impact on surrounding property prices. Proximity to built heritage is captured by distance to listed houses and indicators capturing neighborhoods with built heritage. Impact is assessed by applying a hedonic model to micro-level data and a non-parametric approach to location. While our findings suggest that listed properties do not sell at a premium or discount, heritage-listed buildings are found to have positive external effects on surrounding property prices.
\end{abstract}

Keywords: Cultural economics, built heritage, heritage significance, real estate economics, Berlin JEL classification: R21, R52, Z19

Version: April 2008

\section{Introduction}

The value of cultural heritage in general and built heritage in particular is widely recognized. Selected buildings are registered and listed in order to preserve heritage at the cost of increasing public and private spending (BENHAMOU, 2004). While theoretical work suggests that built heritage may explain the attractiveness of European downtown locations (BRUECKNER, THISSE, \& ZENOU, 1999), there is little empirical evidence. The first empirical approaches explored property transaction data to assess price differentials between listed and non-listed properties. This strand of research aims to identify whether heritage values capitalize into property prices. Most studies that use hedonic approaches or that track the sales prices of heritage-listed properties over time have found positive or at least no negative effects of heritage listing for Australia (DEODHAR, 2004; PENFOLD, 1994), Canada (SHIPLEY, 2000), and the US (ASABERE, HACHEY, \& GRU-

\footnotetext{
* We would like to thank the local Committee of Valuation Experts in Berlin, particularly in person of Thomas Sandner, for providing transaction data. We also thank Jörg Haspel and Hubert Staroste of the Berlin State Office for Historical Monuments and Markus Breithaupt, Wolfgang Nickel and Monika Wosnitzka from the Berlin Senate Department for close cooperation.
} 
BAUGH, 1989; FORD, 1989), whereas CREIGH-TYTE (2000) found adverse effects during the 1980s in the UK and BENHAMOU (2004), demonstrating that the direction of effect depends on the strength of constraints linked to the heritage listing.

However, the results of such studies may vary considerably across countries (BENHAMOU, 2004), which necessitates studies in other regional contexts. In addition, besides assessing price differentials for listed properties, another feasible approach for assessing whether real estate markets value built heritage is to examine the external effects of built heritage on surrounding properties. If listed properties are perceived as valuable location amenities due to appealing appearance and historic importance and real estate markets are in equilibrium, then the closer a location is to the listed properties, the greater its desirability, which will translate into higher property prices. SCHAEFFER \& MILLERICK (1991) provide some evidence for such external benefits within a district in Chicago, Illinois designated as a National Historic District.

This study, besides testing for price differentials of listed properties, aimed to attribute price variation to the location of heritage-listed houses. It is unique in using a rich sample of condominium transactions, micro-level data, recently developed GIS tools, and a spatial econometric approach controlling for housing and location characteristics, as well as for spatial autocorrelation. A hedonic approach was employed to correct property transactions for structural characteristics and details of the purchase agreements. Location was captured in two alternative specifications, either in an amenity-based approach by a set of variables representing location and neighborhood characteristics or in a non-parametric specification where we allowed for a full set of neighborhood fixed effects. Property transaction data were merged with data on 16,142 listed properties and micro-level data disaggregated to the level of 15,937 official statistical blocks. These included area-typical building structures, natural amenities, publicly and privately provided infrastructure, population, including such characteristics as age and origin, automobile registrations, and employment. The external effects of built heritage were assessed using distances to the closest heritage-listed properties and a 
heritage potentiality indicator representing a built heritage environment weighted by the distance from and size of heritage-listed properties.

The remainder of this article is organized as follows. The next section introduces the data. Section three discusses methodological issues and presents our empirical strategy. In section four, we present our empirical results, while the last section presents conclusions.

\section{Data}

Most available hedonic price studies, including a few publications assessing price differentials for listed properties, rely on data on single-family houses. In contrast, we focused on condominium apartment transactions, which account for the vast majority of residential property transactions in Berlin, Germany. In general, condominiums are the most relevant submarket in central European capitals, particularly in downtown areas where built heritage is expected to be of the greatest relevance (BRUECKNER, THISSE, \& ZENOU, 1999). We considered all 6,150 transactions of condominium properties occurring between January and September 2007 in Berlin, which were the most recent data available at the local Committee of Valuation Experts (2007) when the analysis was conducted. After excluding observations with missing values for key characteristics, we conducted our analysis on a sample of 5,769 transactions. Data included the usual parameters such as age, size, number of rooms, and balcony, as well as information on the type of condominium (e.g., maisonette, penthouse, etc.) and contract details containing information on the buyer, seller, type of agreement, and tax privileges, among other things. Based on geographic coordinates, property transactions were georeferenced and merged with data on 16,142 heritage-listed buildings within a GIS-environment. Because we obtained data on protected monuments in form of a shapefile accurate to the ground plan of houses, we were able to identify 494 condominium transactions that occurred within heritage-listed tenements. Figure 1 shows the spatial distribution of condominium transactions considered in this study. The heritage geography of Berlin is shown in Figure 2. 
Fig. 1 Spatial Distribution of Condominium Transactions

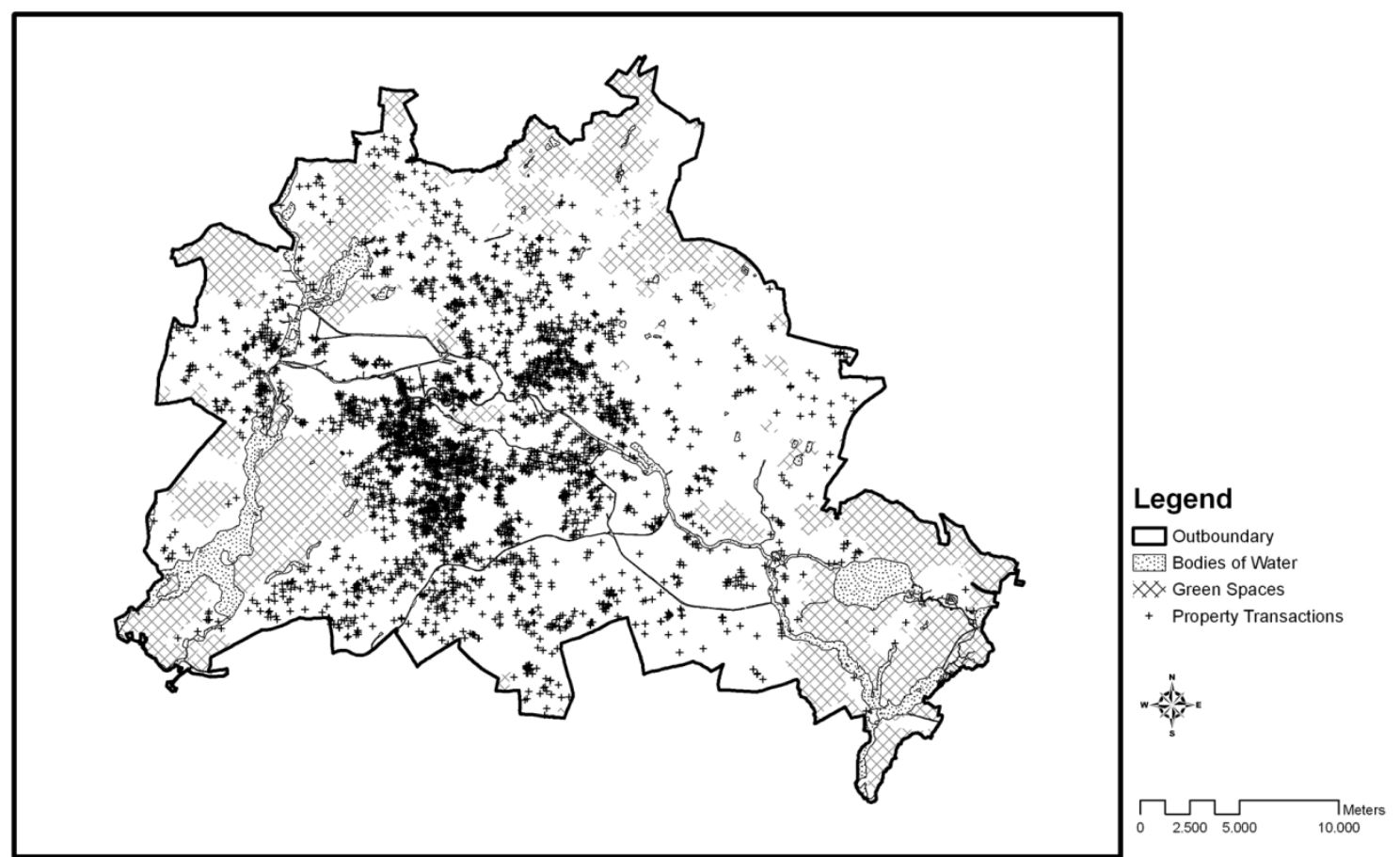

Notes: Map created on the basis of the Urban Environmental Information System.

Source: COMMITTEE OF VALUATION EXPERTS IN BERLIN (2007), SENATSVERWALTUNG FÜR STADTENTWICKLUNG BERLIN (2006).

Fig. 2 Heritage Geography

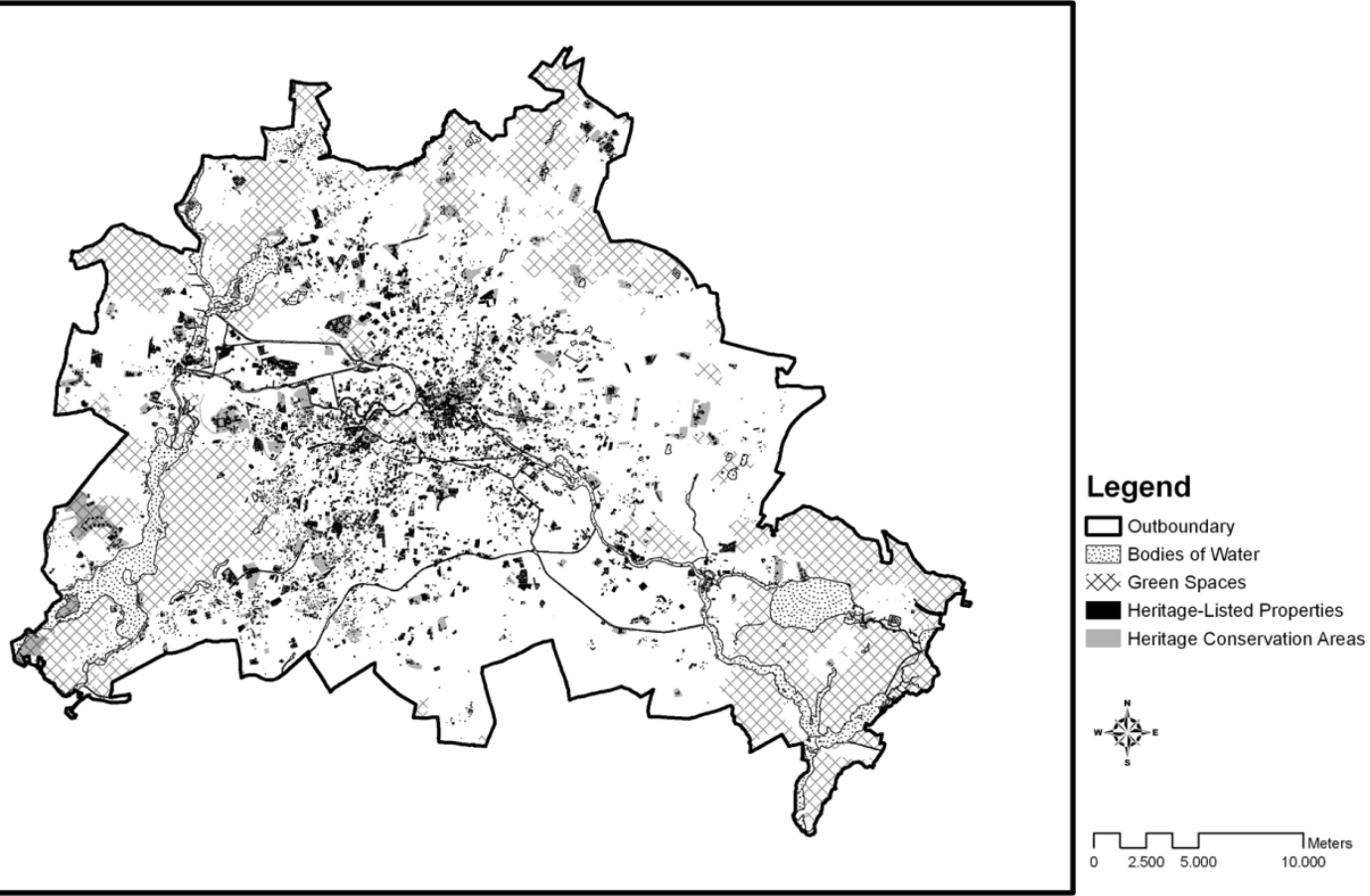

Notes: Map created on the basis of the Urban Environmental Information System.

Source: SENATSVERWALTUNG FÜR STADTENTWICKLUNG BERLIN (2006). 
We controlled for location using variables that capture location and neighborhood characteristics for the whole of Berlin, which on July 31, 2007 had 3,405,483 inhabitants and an area of approximately $892 \mathrm{~km}^{2}$. Data refer to the 15,937 official statistical blocks, the most disaggregated level available at the Statistical Office of Berlin. The statistical blocks have a median surface area of less than 20,000 $\mathrm{m}^{2}$, approximately the size of a typical inner-city block of houses. The mean population of the 12,314 populated blocks was 271 (median 135). Information on public infrastructure such as schools, suburban and metro railway stations and networks, shopping centres, and natural amenities, was used to generate impact variables that are discussed in more detail in the section below. Based on the City and Environmental Information System of the Senate Department, a full set of variables representing typical residential building structures at the block level were also created by applying GIS tools. Furthermore, automobile registrations and population data at block-level were considered, including demographic characteristics and the origin of the resident population. All data used in this paper refer strictly to the end of 2005, with the exception of employment at workplaces, which was only available at the Senate Department for the end of $2003 .^{1}$

\section{Empirical Strategy and Methodological Issues}

Our research strategy basically consisted of two steps. First, we developed a hedonic pricing model explaining property prices using a comprehensive set of structural, location, and neighbourhood characteristics. In the second step, we extended the baseline model to test for price differentials for condominiums that were heritage-listed in order to attribute price variation to monuments' locations. An alternative approach to location was also considered that captured location and neighbourhood characteristics non-parametrically using a full set of neighbourhood fixed effects.

Data on employment at workplaces includes all employees contributing to national social insurance. 
The next sub-sections provide a brief introduction into hedonic modelling, discuss the generation of potentiality variables that capture location characteristics, and present our empirical strategy.

\subsection{Hedonic Modelling}

If real estate markets are in equilibrium, the attractiveness of location is fully capitalised into property prices. The attractiveness of a real estate commodity can be assumed to depend on structural attributes [S], a set of attributes capturing the effects of the neighbourhood $[N]$ and local amenities [L], whose implicit prices are estimated using multiple regression (GALSTER, TATIAN, \& PETTIT, 2004; MUELLBAUER, 1974; ROSEN, 1974). A typical hedonic regression equation may take the following form (TU, 2005).

$$
\log (P)=\alpha+\beta_{1} S_{1}+\ldots+\beta_{i} S_{i}+\gamma_{1} N_{1}+\ldots+\gamma_{j} N_{j}+\delta_{1} L_{1}+\ldots+\delta_{k} L_{k}+\varepsilon
$$

where $P$ is transaction price; $i, j$ and $k$ represent the number of attributes; $\alpha, \beta, \gamma$ and $\delta$ are coefficients; and $\varepsilon$ is an error term. Log-linear specifications are commonly chosen since they allow for non-linearity and are intuitively interpretable. The attribute coefficient gives the percentage impact of changes in attribute values on property values. For coefficient values smaller than $10 \%$, this rule may also be applied to dummy-variables (ELLEN et al., 2001). ${ }^{2}$

Examples of hedonic house pricing models include construction of house indices (CAN \& MEGBOLUGBE, 1997; MILLS \& SIMENAUER, 1996; MUNNEKE \& SLADE, 2001), impact assessment of quality of public services (BOWES \& IHLANFELDT, 2001; GATZLAFF \& SMITH, 1993), school quality (MITCHELL, 2000), group homes (COLWELL, DEHRING, \& LASH, 2000), churches (CAROLL, CLAURETIE, \& JENSEN, 1996), aircraft noise (AHLFELDT \& MAENNIG, 2007a), impact of stadium construction (AHLFELDT \& MAENNIG, 2007b; TU, 2005) and announcement (DEHRING, DEPKEN, \& WARD, 2007) or even supportive housing (GALSTER, TATIAN, \& PETTIT,

\footnotetext{
${ }^{2}$ For larger coefficient values, a simple formula is strongly recommended, which provides a much better approximation. For a parameter estimate $b$ the percentage effect is equal to $\left(e^{b}-1\right)$ (HALVORSEN \& PALMOQUIST, 1980).
} 
2004). SIRMANS, MACPHERSON \& ZIETZ (2005) provide a review and metaanalysis of recent hedonic pricing studies.

Most hedonic studies find that much price variation is explained by standard attributes like age, size, parking, and time of sale (DEHRING, DEPKEN, \& WARD, 2007). We also considered variables denoting the condition and type of condominium (e.g., maisonette, penthouse, etc.) and tenement (e.g., block, row development, etc.), the size of the tenement, the number of stories in the condominium, the number of rooms and numerous features like basements, roof rooms, or balconies. In addition to correcting transactions for property characteristics and sales time, we controlled for agreement type (e.g., purchase, exchange, private, or compulsory auction), buyer and seller (e.g., private, public, institutional investors), whether the condominium was occupied by renters or was subject to tax privileges, rent guarantees, public subsidies, and other legal details.

In our amenity-based approach, in addition to adjusting isolating for unit and transaction characteristics, we addressed details of both location and neighborhood, since our observation area covered both the urban periphery and the core. While traditional approaches restrict themselves to taking into account distances to amenities like green spaces, schools, and railway stations, we allowed for a multidimensional consideration of surrounding amenities.

\subsection{Potentiality Variables}

In the economic geography literature, a long tradition dating back to HARRIS (1954) models agglomeration forces by calculating market access indicators as the distance-weighted sum of population. For instance, if $P_{i}$ is the population of block $i$, then

$$
P P_{i}=\sum_{j} P o P_{j} e^{-a d_{i j}}
$$

is the population potentiality $\left(P P_{i}\right)$ of block $i$, where $P o p_{j}$ is the population of block $j, a$ is a distance decay factor implicitly determining transport costs, and $d_{i j}$ is the straight-line distance between the geographic centroids of blocks $i$ and $j$. Because we dealt with blocks of different size, a basic concept of empirical economic geog- 
raphy (CRAFTS, 2005; KEEBLE, OWENS, \& THOMPSON, 1982) was employed to generate a block internal distance measure based on surface area, which can be used to determine the self-potential:

$$
d_{i i}=\frac{1}{3} \sqrt{\frac{\text { blockarea }_{i}}{\Pi}}
$$

where $d_{i i}$ is block $i$ 's internal distance, equal to one-third of the diameter of a circle of block i's surface area (blockarea $)$.

This concept can be employed to capture natural amenities like bodies of water or green spaces:

$$
A P_{i}=\sum_{j} \operatorname{area}_{j} e^{-a d_{i j}}
$$

where $A P_{i}$ is the potentiality corresponding to the considered amenity (e.g., green spaces or water spaces) for statistical block $i$ and area $_{j}$ is the aggregated surface area of the considered amenity within statistical block $j$. Similarly, a potentiality variable representing a reduced Retail Gravity Model (EPPLI \& SHILLING, 1996) captures shopping opportunities in terms of the spatially discounted retail area: ${ }^{3}$

$$
R P_{i}=\sum_{r} R A_{r} e^{-a d_{i r}}
$$

where $R P_{i}$ is the retail potentiality for block $i, R A_{r}$ is the aggregated retail area of centre $r$ as defined in the centre atlas published by the Senate Department (SENATSVERWALTUNG FÜR WIRTSCHAFT ARBEIT UND FRAUEN, 2004), and $d_{i r}$ is the straight-line distance from block i's geographic centroid to the officially defined central location of the retail centre $r^{4}$

Because of the normally strong correlation between availability of provision with schools and property values (DOWNES \& ZABEL, 2002) we employed an indicator

Shopping has been theoretically proven to be relevant for residents' location choices (ANAS \& KIM, 1996).

4 The centre atlas defines 28 major and minor retail areas. 
representing the availability of schools relative to the population of young people aged 6-18:

$$
R S P_{i}=\frac{\sum_{j} S_{j} e^{-a d_{i j}}}{\sum_{j} R P_{j} e^{-a d_{i j}}},
$$

where $R P S_{j}$ represents the relative school potentiality for block $i, S_{j}$ is the number of schools, and $R P_{j}$ is the relevant population living within block $j$. The parameter $d_{i i}$ is defined as in equation (3) for equations (3) - (5), while $a$ takes the parameter value of 2, which corresponds to walking speed (AHLFELDT, 2007a).

In the empirical urban economic geography literature, distance to central business district (CBD) is considered to be one of the most important location characteristics (CHESHIRE \& SHEPPARD, 1995; DUBIN \& SUNG, 1990; HEIKKILA et al., 1989; ISAKSON, 1997; JORDAAN, DROST, \& MAKGATA, 2004). The original idea that land values decrease with increasing distance from the urban core dates back to VON THÜNEN (1826). ALONSO (1964) postulated the idea of increasing rents due to outbidding of residents who appreciate proximity to employment, which concentrates in the CBD. This concept has fallen under heavy criticism, mostly because it fails to describe the polycentric distribution of employment (GARREAU, 1991; GIULIANO \& SMALL, 1991; MCDONALD, 1987; WHEATON, 1982). LUCAS \& ROSSI-HANSBERG (2002) proved theoretically that an urban polycentric structure represents a stable equilibrium outcome. Berlin is characterised by a striking duo-centricity which emerged during the 1920s and was strengthened during the period of division (ELKINS \& HOFMEISTER, 1988). Modelling Berlin as an ideal mono-centric city could lead to biased estimates (DUBIN \& SUNG, 1990). In past research, this issue has been addressed by considering minimum distances to both CBDs (AHLFELDT \& MAENNIG, 2007a, 2007b). While this concept picks up proximity effects to both urban cores, we added accessibility indicators to account for the uneven spatial distribution of employment. Adopting ALONSO's (1964) idea that residents may be compensated for increasing rents based on their proximity to employment, we represented employment opportunities in terms of spatially aggregated employment at the workplace. To capture 
employment opportunities within walking distance, we employed spatially weighted employment in analogy to equation (1):

$$
E P_{i}=\sum_{j} E_{j} e^{-a d_{i j}}
$$

where $E P_{i}$ is employment potentiality within walking distance of block $i, E j$ is employment at block $j, a$ takes the parameter value of 2 , and $d_{i j}$ is defined as in equation (2).

Accessibility within metropolitan areas is also largely determined by metro-rail and suburban railway networks. We captured accessibility generated by urban railway networks using an indicator on the basis of integrated metro-rail and suburban railway networks that considers both distance to stations and the centrality of stations within the network. This has proven to be a significant determinant of land valuation in Berlin (AHLFELDT, 2007a, 2007b). Employment accessibility generated by the railway network may thus be interpreted as a proxy for centrality in a more general sense, implicitly capturing shopping, cultural, and other central activities that, due to problems of multicollinearity, may not be modelled explicitly.

Assuming that residents use the nearest station, choose the shortest network connection within the combined metro and suburban railway network, and leave the railway system at the station located closest to their place of work, the generation of employment potentiality basically consists of three steps. ${ }^{5}$

Firstly, the employment potentiality of each station within the network is the distance-weighted sum of surrounding blocks' employment:

$$
S P_{m}=\sum_{j} E_{j} e^{\left(-b d_{m j}\right)}
$$

5 The combined Berlin metro and suburban railway network consists of 275 stations and has a length of $475 \mathrm{~km}$. Yearly passenger numbers come to approximately 790 million (2006) [URL: www.oepnv-berlin.de $(07 / 01 / 11)]$. 
where $S P_{m}$ is the employment potentiality of station $m, E_{j}$ is employment at workplaces of block $j, b$ is a distance decay factor taking the value of 2 , and $d_{m j}$ is the straight-line distance between station $m$ and block $j$.

Secondly, employment potentiality generated by the rail network is the distanceweighted sum of the station potentialities of all other stations within the network:

$$
N S P_{s}=\sum_{m} S P_{m} e^{\left(-a d_{s m}\right)}, \text { for } m \neq S
$$

where $N S P_{s}$ is the employment potentiality of station $s$, which can be thought of as the potential for a resident who lives immediately adjacent to station $s$ and wishes to commute by rail-based public transportation. Decay parameter $a$ takes the value of 0.5 to account for train velocity, and $d_{s m}$ is the shortest network distance between stations $s$ and $m$. Stations' self-potentials are not considered since residents living and working within the catchment area of the same station will obviously not take the train. ${ }^{6}$

Finally, as commuters typically do not live within railway stations, network station potentiality has to be discounted by the distance from the residence in order to reflect the transport costs of walking to the nearest railway station:

$$
E P_{-} \text {Rail }_{t}=N S P_{s} e^{\left(-b d_{t s}\right)} \text {, }
$$

where EP_Rail ${ }_{t}$ is the employment potentiality generated by the urban railway network at the location of transaction $t, b$ takes the value of 2 , and $d_{t s}$ is the distance from transaction $t$ to the nearest station $s$. Combining equations (6) - (8), employment potentiality can be written as:

$$
E P \text { Rail }_{t}=e^{\left(-b d_{t s}\right)} \sum_{m}\left(\sum_{j} E_{j} e^{\left(-b d_{m j}\right)}\right) e^{\left(-a d_{s m}\right)}, \text { for } m \neq S
$$

${ }^{6}$ The employment potential is captured by the employment access indicator based on walking speed. 
The potentiality concept is also adopted to generate a heritage indicator representing a given location's endowment with built heritage. We spatially aggregated heritage-listed houses corresponding to equation (3), where area represents the aggregated building area of heritage-listed houses within block $i$. Figures 3 and 4 compare employment and heritage potentiality in three-dimensional space. While Figure 2 shows the locations of all heritage-listed properties, the heritage potentiality in Figure 4 illustrates endowment with built-heritage, taking into account all surrounding heritage-listed properties weighted by distance and size for each of 15,937 statistical blocks. The figures reveal a striking similarity, which highlights the high concentration of built heritage in downtown areas, which is typical for European metropolises (BRUECKNER, THISSE, \& ZENOU, 1999).

\section{Fig. 3 Employment Potentiality}

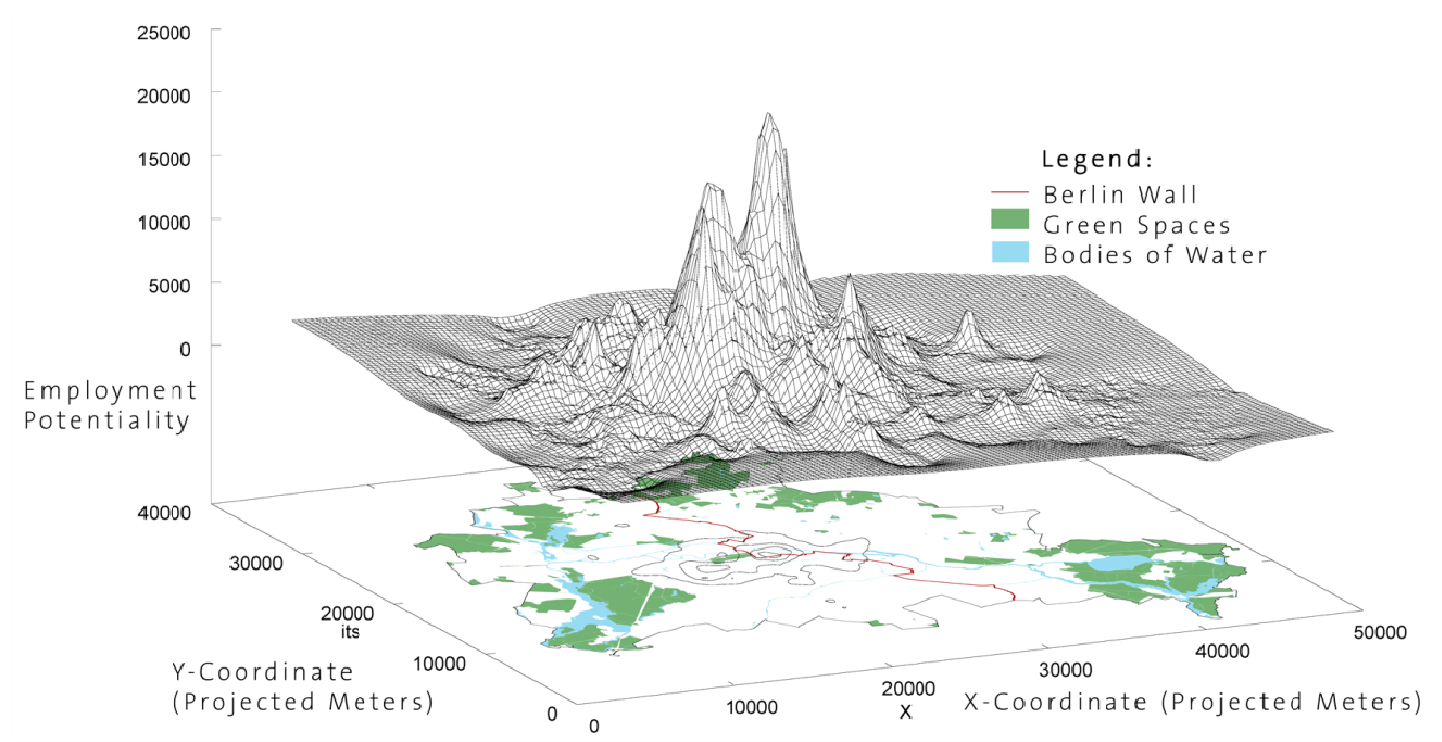

Notes: The figure represents block-level employment potentiality as defined in equation (6) assuming a decay parameter $a$ of 2 . Coordinates refer to the "Soldner" coordinate system used by the Senate Department of Berlin. 
Fig. 4 Heritage Potentiality

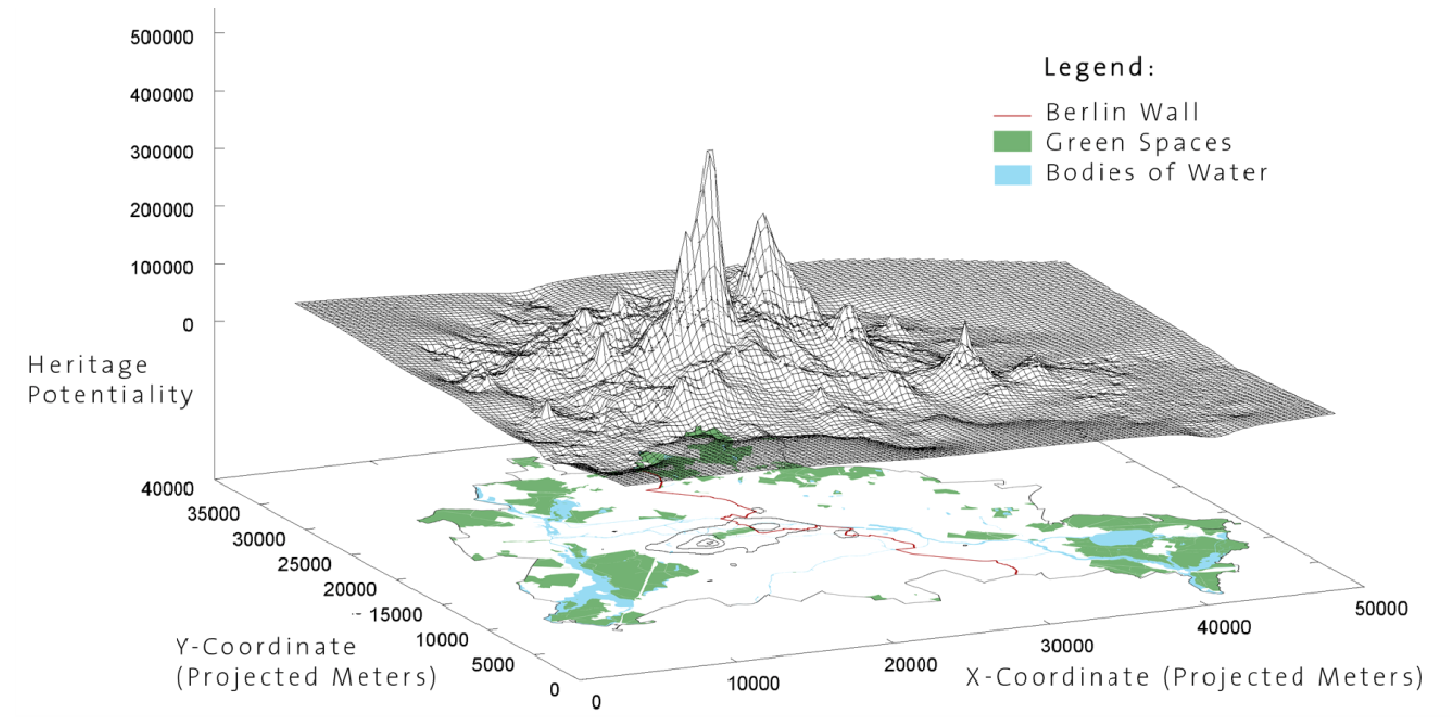

Source: The figure represents block level heritage potentiality as defined in equation (3) assuming a decay parameter $a$ of 2 . Coordinates refer to the "Soldner" coordinate system used by the Senate Department of Berlin.

\subsection{Empirical Strategy}

We followed a standard hedonic approach to assess implicit prices of transaction and location characteristics. Our baseline model was then extended to assess the impact of heritage-listing and the external effects of heritage-listed houses. Two alternative specifications were considered to control for location. In our amenitybased approach we controlled for location using variables that capture accessibility, shopping opportunities, natural amenities, and a set of dummy variables representing area-typical building structures. Neighbourhood was captured by the density and composition of the resident population and by automobile registrations per capita.

$$
\begin{aligned}
\log \left(P_{t}\right) & =\alpha+\text { TRANSACTION }_{t} a_{1}+\operatorname{LOC}_{t} a_{2}+\text { NEIGH }_{t} a_{3}+\text { HERITAGE }_{t} a_{4}, \\
& +\beta \text { Spatial_Lag }+\varepsilon_{t},
\end{aligned}
$$

where TRANSACTION is a vector of transaction attributes, including unit and contract characteristics, time trends, and monthly dummies. $L O C$ is a vector of location attributes capturing accessibility, natural endowments, and availability of public and private services, as discussed in the subsection above. NEIGH is a vector capturing block density, the composition of the resident population, and 
automobile registrations per capita. HERITAGE is a vector of heritage characteristics. $\alpha, \beta$ and $a_{x}$ represent the set of coefficients to be estimated and $\varepsilon$ is a random error Term. Spatial_Lag is a spatial autoregressive term accounting for spatial autocorrelation, which may result when omitted variables are correlated across space or transaction prices are endogenous transactions occurring in the vicinity. The lag term is a distance-weighted average of transactions occurring within the same neighbourhood, and it takes the following form for transaction $t$ :

$$
\text { Spatial_Lag }=\sum_{u} \frac{\left(1 / d_{t u}\right)}{\sum_{u} 1 / d_{t u}} P_{-} \text {sqm }_{u},
$$

where $P_{-}$sqm $_{u}$ is the sales price per square meter of transaction $u$ and $\left(1 / d_{t u}\right)$ represents the inverse of the distance between the centroids of blocks $t$ and $u$. Here, the lag term considers the three nearest transactions in each case, as suggested by CAN \& MEGBOLUGBE (1997). To account for spatial correlation affecting the variance of sales prices, we clustered standard errors on statistical blocks (DEHRING, DEPKEN, \& WARD, 2007).

In our alternative specification, we chose to control for location nonparametrically by introducing a full set of neighbourhood fixed effects. Two levels of neighbourhoods were specified for robustness tests: traffic cells ("Verkehrszellen") dividing Berlin into 338 sections, and statistical blocks drawn from the micro-level data used in our amenity-based approach. This specification addressed spatial autocorrelation by allowing for mean-shifting and variance-shifting (DEHRING, DEPKEN, \& WARD, 2007). Again, variance was allowed to vary across space by clustering standard errors on the respective level of neighbourhood. Our alternative specification thus took following form:

$$
\begin{gathered}
\log \left(P_{t}\right)=\gamma+\operatorname{TRANSACTION}_{t} b_{1}+\operatorname{HERITAGE}_{t} b_{2}+\mu_{t} \\
\text { where } \mu_{t}=\theta_{t}+\varphi_{t}
\end{gathered}
$$

TRANSACTION and HERITAGE are the same as in equation (10), $\gamma$ and $b_{\mathrm{x}}$ are coefficients to be estimated, and $\mu_{t}$ is a composite zero-mean error term allowing for neighborhood fixed effects $\left(\theta_{t}\right)$ and a random component $\left(\varphi_{t}\right)$. 
Heritage characteristics include dummy variables denoting transactions occurring within heritage-listed buildings to identify whether there are significant price differentials. The external effects of heritage-listed houses are assessed by considering distance to the closest heritage-listed building and heritage potentiality as defined in the subsection above.

\section{Empirical Results}

\subsection{Baseline Models}

Complete empirical results from our baseline models are presented in Table A1. Prices increased at a decreasing rate with condominium size. Features such as the number of living rooms and the presence of a balcony, hobby room, roof room, or garage had positive effects on sale prices. We found significantly positive price differentials for penthouses and attic flats, whereas condominiums at or below street level sold at discounts. Age and bad condition also caused price depreciation, with the condominium's condition being more important than the condition of the respective tenement. Agreement details such as the constellation of buyers and sellers also had a significant impact on sale prices. Prices realized in auctions tended to be significantly lower compared to those associated with standard purchasing procedures. Significantly higher prices resulted in transactions where non-profit housing associations, fund companies, religious communities, or other corporate bodies were involved as buyers. In contrast, companies constituted under civil law, public authorities, and other corporate bodies selling properties tended to realize premiums. While rent guarantees and additional joint property raised sale prices, condominiums that were occupied or leased by renters or that belonged to social housing projects sold at discounts.

Our amenity-based approach yielded additional insights about location and neighborhood as determinants of property prices. Positive price differentials are attributable to established areas of low housing density, but not for areas of low housing density covered with buildings in the 1990s. In line with theory, proximity to CBD was highly statistically significant. The significance of shopping potentiality indicates that access to minor shopping centers positively affects location 
desirability, while for our sample of condominium transactions no significant effects for employment potentiality corresponding to walking speed and urban railway network were observed. The latter might be attributable to condominium transactions that occur largely within downtown tenement blocks located in areas that are similarly well connected to the railway network. Similar reasoning may explain the statistical insignificance of relative school potentiality. Somewhat surprisingly, the coefficient on green potentiality was significantly negative. Confirming the above mentioned effects of housing density, population density had a significantly negative impact on condominium prices. The coefficient on the proportion of foreign-born residents, which - in Berlin - can be interpreted as a proxy for socially disadvantaged areas, was also significantly negative. In contrast, the coefficient for automobile registrations per capita, presumably positively correlated with income, was significantly positive, as expected.

\subsection{Impact of Built Heritage}

The baseline models presented in Table A1 are extended by variables that attribute price variation to heritage attributes. Empirical results for extended hedonic models corresponding to our amenity-based approach are shown in Table 1.

Tab. 1 Results for Extended Models (Amenity-Based Approach)

\begin{tabular}{lcccc}
\hline \hline & $(1)$ & $(2)$ & $(3)$ & $(4)$ \\
& $\log ($ Price $)$ & $\log ($ Price $)$ & $\log ($ Price $)$ & Log(Price) \\
\hline Monument & -0.02143 & & & -0.01556 \\
& $(0.0217)$ & & & $(0.03780)$ \\
Distance to Monument & & -0.02455 & & \\
Heritage Potentiality & & $(0.03725)$ & & \\
& & & $0.00533^{* * *}$ & $0.00547^{* * *}$ \\
\hline Spatial Lag & Yes & & $(0.00168)$ & $(0.00180)$ \\
Fixed Effects & - & - & Yes & Yes \\
Observations & 5720 & 5309 & 5720 & - \\
R squared & 0.7862 & 0.7896 & 0.7904 & 0.7905 \\
\hline \hline
\end{tabular}

Notes: The basic model is model (1) of Table A1. To save space, results are presented for heritage variables only. Robust standard errors (in parenthesis) are clustered on statistical blocks. ${ }^{*}$ denotes significance at the $10 \%$ level; ${ }^{* *}$ denotes significance at the $5 \%$ level; ${ }^{* * *}$ denotes significance at the $1 \%$ level.

Based on the geographic coordinates of property transactions and a precise electronic map of heritage-listed properties, we defined a dummy variable (Monu- 
ment) identifying all property transactions occurring within heritage-listed buildings. In model (1) of Table 1, we introduced this dummy variable into our amenity-based hedonic model environment. The coefficient on Monument was not statistically significant at conventional levels, indicating that there were no significant price-differentials for the listed properties. This result suggests that the potentially negative effects of development constraints and maintenance obligations may be cancelled out by the potentially positive effects from tax abatement, the intangible value of historic importance, and aesthetic appeal.

To assess whether the external effects of heritage-listed buildings capitalize into property prices, we introduced shortest straight-line distances to heritage-listed buildings (Distance to Monument) and heritage potentiality as defined in the methodological section. To avoid bias, we excluded transactions occurring within heritage-listed buildings when assessing the impact of distance to the closest monument. The results shown in column 2 of Table 1 reveal that simple proximity to the closest monument was not a significant price determinant.

However, the coefficient on heritage potentiality, which takes into account all neighboring monuments weighted by distance and size, was highly statistically significant (column 3, Table 1). Thus, positive external effects due to heritagelisted buildings become measurable when considering the whole ensemble of monuments within the neighborhood. This dimension has to be considered when assessing price differentials for heritage-listed properties. Since monuments are likely to cluster, a positive impact on property prices may erroneously be attributed to a property being heritage-listed, when in fact it is benefiting from external effects due to neighboring monuments. Therefore, in column 4 of Table 1, we reassessed price differential for heritage-listed properties while controlling for monuments within the neighborhood by heritage potentiality. The results proved to be robust in that we found no significant impact of heritage listing, even though a neighborhood containing many heritage-listed buildings is perceived as a valuable location amenity.

In Table 2, we repeated the estimates from Table 1 while controlling for location non-parametrically using a full set of block fixed effects. The baseline specifica- 
tion corresponds to column 2 of Table A1. The pattern of impact is analogous to that in Table 1, providing evidence for the estimates' robustness. The results were also robust to changing levels of neighborhood fixed effects. Extended models for baseline specification with traffic cell fixed effects are presented in Table A2 in the appendix.

Tab. 2 Results for Extended Models (Statistical Block Fixed Effects)

\begin{tabular}{lcccc}
\hline \hline & $(1)$ & $(2)$ & $(3)$ & $(4)$ \\
& $\log ($ Price $)$ & $\log ($ Price $)$ & $\log ($ Price $)$ & Log(Price) \\
\hline Monument & 0.01153 & & & 0.01153 \\
& $(0.04503)$ & & & $(0.04503)$ \\
Distance to Monument & & 0.54481 & & \\
Heritage Potentiality & & $(0.35097)$ & & \\
& & & $0.04726^{* * *}$ & $0.04727^{* * *}$ \\
Spatial Lag & & & $(0.00328)$ & $(0.00329)$ \\
Fixed Effects & - & - & - & - \\
Observations & Stat. Blocks & Stat. Blocks & Stat. Blocks & Stat. Blocks \\
R squared & 5769 & 5324 & 5769 & 5769 \\
\hline \hline
\end{tabular}

Notes: Variables are defined as in Table 1. The basic model is model (2) of Table A1. To save space results are presented for heritage variables only. Robust standard errors (in parenthesis) are clustered on traffic cells. ${ }^{*}$ denotes significance at the $10 \%$ level; ${ }^{* *}$ denotes significance at the $5 \%$ level; ${ }^{* * *}$ denotes significance at the $1 \%$ level.

\section{Conclusion}

This study adds to the discussion on the value of built heritage by a) making use of GIS-tools, detailed transaction data, and highly disaggregated data on location and neighborhood, and b) assessing the internal and external price impacts of heritage listing. While no significant price differentials were found for heritagelisted buildings, indicating that positive and negative effects cancel each other out, compelling evidence was found that built heritage positively affects the prices of surrounding properties. Given that properties are chosen for heritage listing due to outstanding architectural quality (CREIGH-TYTE, 1998), there is evidence for architecture representing a source of positive externalities capitalizing into the prices of neighboring properties.

Our results proved to be robust to changes in model specifications, and they controlled for neighboring monuments when assessing the impact of heritage listing. 
In light of our results, future research on the impact of heritage listing should focus on the built heritage environment. Considering that monuments are likely to cluster, property values may appear to be raised by heritage listing, when in fact, the owners of heritage-listed properties are benefiting from external effects due to neighboring monuments. This distinction is crucial when determining whether owners of heritage-listed houses are appropriately compensated for legal constraints and obligations. Indeed, our results suggest that the legal system should incentivize the conservation of monuments because of their positive external effects on the neighboring community.

One important finding from this study is that it is worth conserving the fabric of built heritage as a whole. While the aesthetic appeal of particular buildings of historical importance may be indisputable, our results suggest that, more than proximity to a single monument, it is the totality of the built environment that constitutes the amenity recognized by real estate markets. Thus the urban environment adheres to a principle stated by Aristotle over 2000 years ago in a more general context: "The whole is more than the sum of its parts". 


\section{Appendix}

Tab. A1 Results for Baseline Models (I-V)

\begin{tabular}{|c|c|c|c|}
\hline & $\begin{array}{c}(1) \\
\log (\text { Price })\end{array}$ & $\begin{array}{c}(2) \\
\log (\text { Price })\end{array}$ & $\begin{array}{c}(3) \\
\log (\text { Price) }\end{array}$ \\
\hline Block Development & $\begin{array}{c}0.13748 \\
(0.17644)\end{array}$ & $\begin{array}{l}-0.02602 \\
(0.40750)\end{array}$ & $\begin{array}{c}0.20810 \\
(0.18204)\end{array}$ \\
\hline Row Development & $\begin{array}{c}0.17211 \\
(0.17747)\end{array}$ & $\begin{array}{l}0.00126 \\
(0.41744)\end{array}$ & $\begin{array}{c}0.23519 \\
(0.18427)\end{array}$ \\
\hline Detached Houses & $\begin{array}{c}0.21936 \\
(0.17502)\end{array}$ & $\begin{array}{c}0.03649 \\
(0.41059)\end{array}$ & $\begin{array}{r}0.31241^{*} \\
(0.17992)\end{array}$ \\
\hline Semidetached Houses & $\begin{array}{c}0.27822 \\
(0.18816)\end{array}$ & $\begin{array}{l}-0.26553 \\
(0.27916)\end{array}$ & $\begin{array}{r}0.35581^{*} \\
(0.19386)\end{array}$ \\
\hline Row Houses & $\begin{array}{r}0.33924^{*} \\
(0.18680)\end{array}$ & $\begin{array}{l}-0.02161 \\
(0.30026)\end{array}$ & $\begin{array}{l}0.45759^{* *} \\
(0.18243)\end{array}$ \\
\hline Yard Development & $\begin{array}{c}0.11841 \\
(0.17746)\end{array}$ & $\begin{array}{l}-0.07511 \\
(0.40914)\end{array}$ & $\begin{array}{c}0.20894 \\
(0.18306)\end{array}$ \\
\hline Tenement Stories & $\begin{array}{c}0.00491 \\
(0.00861)\end{array}$ & $\begin{array}{c}0.01282 \\
(0.02698)\end{array}$ & $\begin{array}{c}0.01709 \\
(0.01413)\end{array}$ \\
\hline Tenement Stories squared & $\begin{array}{l}-0.00060^{* *} \\
(0.00030)\end{array}$ & $\begin{array}{l}-0.00133 \\
(0.00150)\end{array}$ & $\begin{array}{l}-0.00167^{* *} \\
(0.00069)\end{array}$ \\
\hline Tenement Size $\left(10,000 \mathrm{~m}^{2}\right)$ & $\begin{array}{l}0.06953^{* *} \\
(0.03486)\end{array}$ & $\begin{array}{c}0.10233 \\
(0.10681)\end{array}$ & $\begin{array}{c}0.06570 \\
(0.04917)\end{array}$ \\
\hline Tenement Size $\left(10,000 \mathrm{~m}^{2}\right)$ squared & $\begin{array}{l}-0.01423 \\
(0.01147)\end{array}$ & $\begin{array}{l}-0.03947 \\
(0.02512)\end{array}$ & $\begin{array}{l}-0.00180 \\
(0.02114)\end{array}$ \\
\hline $\begin{array}{l}\text { Commercial Area }\left(10,000 \mathrm{~m}^{2}\right) \\
\text { in Tenement }\end{array}$ & $\begin{array}{l}-0.03821 \\
(0.13092)\end{array}$ & $\begin{array}{l}-0.24070 \\
(0.69647)\end{array}$ & $\begin{array}{l}-0.41807 \\
(0.25797)\end{array}$ \\
\hline Elevator & $\begin{array}{c}0.00819 \\
(0.01573)\end{array}$ & $\begin{array}{c}0.02390 \\
(0.03234)\end{array}$ & $\begin{array}{c}0.02613 \\
(0.02218)\end{array}$ \\
\hline Below Street Level & $\begin{array}{l}-0.39646^{* * *} \\
(0.12816)\end{array}$ & $\begin{array}{l}-0.25004 \\
(0.18607)\end{array}$ & $\begin{array}{l}-0.24016^{*} \\
(0.13789)\end{array}$ \\
\hline Street Level & $\begin{array}{l}-0.05793^{* * *} \\
(0.01667)\end{array}$ & $\begin{array}{l}-0.03612^{*} \\
(0.02144)\end{array}$ & $\begin{array}{l}-0.04520^{* *} \\
(0.01785)\end{array}$ \\
\hline Story & $\begin{array}{c}0.00386 \\
(0.00394)\end{array}$ & $\begin{array}{c}0.00883^{* *} \\
(0.00430)\end{array}$ & $\begin{array}{c}0.00741 \\
(0.00452)\end{array}$ \\
\hline Penthouse & $\begin{array}{l}0.53326^{* * *} \\
(0.17101)\end{array}$ & $\begin{array}{r}0.39886^{*} \\
(0.23406)\end{array}$ & $\begin{array}{l}0.45669^{* * *} \\
(0.14051)\end{array}$ \\
\hline Maisonette & $\begin{array}{l}-0.03062 \\
(0.04588)\end{array}$ & $\begin{array}{l}-0.00600 \\
(0.05275)\end{array}$ & $\begin{array}{l}-0.01170 \\
(0.04593)\end{array}$ \\
\hline Attic Flat & $\begin{array}{l}0.12792^{* * *} \\
(0.02790)\end{array}$ & $\begin{array}{l}0.09524^{* *} \\
(0.04708)\end{array}$ & $\begin{array}{l}0.12337^{* * *} \\
(0.03216)\end{array}$ \\
\hline Terrace Flat & $\begin{array}{c}0.11391 \\
(0.24147)\end{array}$ & $\begin{array}{l}-0.31078 \\
(0.23558)\end{array}$ & $\begin{array}{c}0.11160 \\
(0.23197)\end{array}$ \\
\hline Shop Flat & $\begin{array}{l}-0.03341 \\
(0.10990)\end{array}$ & $\begin{array}{l}-0.00597 \\
(0.18247)\end{array}$ & $\begin{array}{c}0.10894 \\
(0.14938)\end{array}$ \\
\hline
\end{tabular}


Tab. A1. Results for Baseline Models (II-V)

\begin{tabular}{|c|c|c|c|}
\hline & $\begin{array}{c}(1) \\
\log (\text { Price) }\end{array}$ & $\begin{array}{c}(2) \\
\text { Log(Price) }\end{array}$ & $\begin{array}{c}(3) \\
\log (\text { Price) }\end{array}$ \\
\hline Homestead & $\begin{array}{l}-0.01011 \\
(0.07273)\end{array}$ & $\begin{array}{c}0.27174 \\
(0.36294)\end{array}$ & $\begin{array}{c}0.02316 \\
(0.08777)\end{array}$ \\
\hline Size (sqm) & $\begin{array}{l}0.02201^{* * *} \\
(0.00100)\end{array}$ & $\begin{array}{l}0.02353^{* * *} \\
(0.00140)\end{array}$ & $\begin{array}{l}0.02253^{* * *} \\
(0.00104)\end{array}$ \\
\hline Size (sqm) squared & $\begin{array}{l}-0.00005^{* * *} \\
(0.00000)\end{array}$ & $\begin{array}{l}-0.00006^{* * *} \\
(0.00001)\end{array}$ & $\begin{array}{l}-0.00005^{* * *} \\
(0.00000)\end{array}$ \\
\hline Number of Living Rooms & $\begin{array}{c}0.01921^{* *} \\
(0.00855)\end{array}$ & $\begin{array}{c}0.01892 \\
(0.01410)\end{array}$ & $\begin{array}{c}0.01838^{*} \\
(0.01058)\end{array}$ \\
\hline Pantry Kitchen & $\begin{array}{r}0.10414^{*} \\
(0.05830)\end{array}$ & $\begin{array}{c}0.19216 \\
(0.11989)\end{array}$ & $\begin{array}{c}0.07500 \\
(0.07766)\end{array}$ \\
\hline Vestibule & $\begin{array}{c}0.01072 \\
(0.01452)\end{array}$ & $\begin{array}{c}0.01688 \\
(0.02491)\end{array}$ & $\begin{array}{l}-0.01097 \\
(0.01803)\end{array}$ \\
\hline Store Room & $\begin{array}{l}-0.00624 \\
(0.01218)\end{array}$ & $\begin{array}{c}0.00808 \\
(0.01952)\end{array}$ & $\begin{array}{l}-0.00573 \\
(0.01535)\end{array}$ \\
\hline Balcony & $\begin{array}{l}0.03784^{* * *} \\
(0.01237)\end{array}$ & $\begin{array}{c}0.03571^{*} \\
(0.01892)\end{array}$ & $\begin{array}{l}0.03513^{* *} \\
(0.01615)\end{array}$ \\
\hline Artist Studio & $\begin{array}{l}-0.08044 \\
(0.17880)\end{array}$ & $\begin{array}{c}0.13685 \\
(0.21607)\end{array}$ & $\begin{array}{c}0.01866 \\
(0.16319)\end{array}$ \\
\hline Hobby Room & $\begin{array}{l}0.13434^{* * *} \\
(0.04426)\end{array}$ & $\begin{array}{c}0.11668 \\
(0.09236)\end{array}$ & $\begin{array}{l}0.11330^{* * *} \\
(0.04208)\end{array}$ \\
\hline Basement Room & $\begin{array}{l}-0.01575 \\
(0.01358)\end{array}$ & $\begin{array}{l}-0.01900 \\
(0.03420)\end{array}$ & $\begin{array}{l}-0.02958 \\
(0.01797)\end{array}$ \\
\hline Roof Room & $\begin{array}{l}0.14070^{* * *} \\
(0.04385)\end{array}$ & $\begin{array}{c}0.09796 \\
(0.10246)\end{array}$ & $\begin{array}{c}0.09138 \\
(0.05878)\end{array}$ \\
\hline Garage & $\begin{array}{c}0.04692 \\
(0.03146)\end{array}$ & $\begin{array}{l}-0.04867 \\
(0.07598)\end{array}$ & $\begin{array}{l}0.07715^{* *} \\
(0.03794)\end{array}$ \\
\hline Parking Lot & $\begin{array}{c}0.04027 \\
(0.02615)\end{array}$ & $\begin{array}{l}-0.01840 \\
(0.04725)\end{array}$ & $\begin{array}{c}0.04434 \\
(0.03590)\end{array}$ \\
\hline Easement at Plot & $\begin{array}{l}0.06465^{* *} \\
(0.02854)\end{array}$ & $\begin{array}{c}0.04255 \\
(0.03942)\end{array}$ & $\begin{array}{l}0.11554^{* * *} \\
(0.03028)\end{array}$ \\
\hline Age & $\begin{array}{l}-0.00258^{* * *} \\
(0.00099)\end{array}$ & $\begin{array}{l}-0.00611^{*} \\
(0.00339)\end{array}$ & $\begin{array}{l}-0.00408^{* * *} \\
(0.00155)\end{array}$ \\
\hline Age squared & $\begin{array}{l}0.00002^{* * *} \\
(0.00001)\end{array}$ & $\begin{array}{l}0.00005^{*} \\
(0.00003)\end{array}$ & $\begin{array}{l}0.00003^{* * *} \\
(0.00001)\end{array}$ \\
\hline Condominium in Bad Condition & $\begin{array}{l}-0.40715^{* * *} \\
(0.06380)\end{array}$ & $\begin{array}{l}-0.45467^{* * *} \\
(0.10238)\end{array}$ & $\begin{array}{l}-0.46389^{* * *} \\
(0.07347)\end{array}$ \\
\hline Tenement in Bad Condition & $\begin{array}{l}-0.16155 \\
(0.18924)\end{array}$ & $\begin{array}{l}-0.45315^{*} \\
(0.27273)\end{array}$ & $\begin{array}{l}-0.42073^{* *} \\
(0.17038)\end{array}$ \\
\hline Exchange & $\begin{array}{l}-0.18819^{* * *} \\
(0.07274)\end{array}$ & $\begin{array}{l}1.15961^{* * *} \\
(0.12484)\end{array}$ & $\begin{array}{l}-0.05927 \\
(0.06054)\end{array}$ \\
\hline Compulsory Auction & $\begin{array}{c}0.15157 \\
(0.10458)\end{array}$ & $\begin{array}{c}0.06886 \\
(0.14673)\end{array}$ & $\begin{array}{c}0.08346 \\
(0.12594)\end{array}$ \\
\hline
\end{tabular}


Tab. A1. Results for Baseline Models (III-V)

\begin{tabular}{|c|c|c|c|}
\hline & $\begin{array}{c}(1) \\
\log (\text { Price) }\end{array}$ & $\begin{array}{c}(2) \\
\log (\text { Price) }\end{array}$ & $\begin{array}{c}\text { (3) } \\
\log (\text { Price) }\end{array}$ \\
\hline Private Auction & $\begin{array}{l}-0.20773^{* * *} \\
(0.05493)\end{array}$ & $\begin{array}{c}0.02250 \\
(0.10786)\end{array}$ & $\begin{array}{l}-0.15579^{* *} \\
(0.06493)\end{array}$ \\
\hline Buyer is Comp. Const. Under Civil Law & $\begin{array}{l}-0.01512 \\
(0.06329)\end{array}$ & $\begin{array}{l}-0.04514 \\
(0.08057)\end{array}$ & $\begin{array}{c}0.01648 \\
(0.07397)\end{array}$ \\
\hline Buyer is Non-Profit Housing Association & $\begin{array}{l}-0.16502^{* * *} \\
(0.03419)\end{array}$ & $\begin{array}{l}-0.27354^{* * *} \\
(0.03022)\end{array}$ & $\begin{array}{l}-0.24893^{* * *} \\
(0.04706)\end{array}$ \\
\hline Buyer is Insurance Company & $\begin{array}{l}-0.37054 \\
(0.50866)\end{array}$ & $\begin{array}{l}-0.76683 \\
(0.56646)\end{array}$ & $\begin{array}{l}-0.29204 \\
(0.49842)\end{array}$ \\
\hline Buyer is other Corporate Body & $\begin{array}{l}-0.20679^{* * *} \\
(0.02501)\end{array}$ & $\begin{array}{l}-0.25445^{* * *} \\
(0.04783)\end{array}$ & $\begin{array}{l}-0.24126^{* * *} \\
(0.03581)\end{array}$ \\
\hline Seller is Comp. Const. Under Civil Law & $\begin{array}{l}0.07812^{* * *} \\
(0.02836)\end{array}$ & $\begin{array}{c}0.08593 \\
(0.06271)\end{array}$ & $\begin{array}{l}0.10641^{* *} \\
(0.04262)\end{array}$ \\
\hline Seller is Public Fund & $\begin{array}{l}-0.17674^{* * *} \\
(0.05173)\end{array}$ & $\begin{array}{l}1.01822^{* * *} \\
(0.13417)\end{array}$ & $\begin{array}{l}-0.25469^{* * *} \\
(0.06115)\end{array}$ \\
\hline Seller is Non-Profit Housing Association & $\begin{array}{c}0.00530 \\
(0.02676)\end{array}$ & $\begin{array}{l}-0.07658 \\
(0.06207)\end{array}$ & $\begin{array}{l}-0.00057 \\
(0.05052)\end{array}$ \\
\hline Seller is Public Authority & $\begin{array}{l}0.10399^{* *} \\
(0.04669)\end{array}$ & $\begin{array}{l}0.16937^{* * *} \\
(0.03985)\end{array}$ & $\begin{array}{l}0.16745^{* * *} \\
(0.05834)\end{array}$ \\
\hline Seller is Fond Company & $\begin{array}{l}-0.38022^{* * *} \\
(0.04010)\end{array}$ & $\begin{array}{l}-0.12144 \\
(0.08841)\end{array}$ & $\begin{array}{l}-0.09183^{*} \\
(0.04816)\end{array}$ \\
\hline Seller is other Corporate Body & $\begin{array}{l}0.14357^{* * *} \\
(0.01871)\end{array}$ & $\begin{array}{l}0.15877^{* * *} \\
(0.03989)\end{array}$ & $\begin{array}{l}0.21059^{* * *} \\
(0.02549)\end{array}$ \\
\hline Seller Religious Community & $\begin{array}{l}-0.11022 \\
(0.13728)\end{array}$ & $\begin{array}{l}-0.30940^{* * *} \\
(0.11955)\end{array}$ & $\begin{array}{l}-0.24485^{*} \\
(0.14824)\end{array}$ \\
\hline Seller is Public Housing Association & $\begin{array}{r}0.07028^{*} \\
(0.04105)\end{array}$ & $\begin{array}{c}0.12309 \\
(0.08023)\end{array}$ & $\begin{array}{l}0.13177^{* *} \\
(0.06623)\end{array}$ \\
\hline Condominium is Occupied by Renter & $\begin{array}{l}-0.04492^{* * *} \\
(0.01469)\end{array}$ & $\begin{array}{l}-0.05844^{* *} \\
(0.02557)\end{array}$ & $\begin{array}{l}-0.05133^{* *} \\
(0.02449)\end{array}$ \\
\hline Condominium is Leased & $\begin{array}{l}-0.18208^{* * *} \\
(0.03145)\end{array}$ & $\begin{array}{l}-0.21035^{* * *} \\
(0.04472)\end{array}$ & $\begin{array}{l}-0.23803^{* * *} \\
(0.04232)\end{array}$ \\
\hline Social Housing & $\begin{array}{l}-0.06297^{* * *} \\
(0.01972)\end{array}$ & $\begin{array}{l}-0.10796^{* *} \\
(0.05316)\end{array}$ & $\begin{array}{l}-0.07338^{* *} \\
(0.03150)\end{array}$ \\
\hline Tax Privileged Housing & $\begin{array}{l}-0.06160 \\
(0.03752)\end{array}$ & $\begin{array}{l}-0.10888 \\
(0.11735)\end{array}$ & $\begin{array}{l}-0.06546 \\
(0.04208)\end{array}$ \\
\hline Rent Regulation & $\begin{array}{c}0.09939 \\
(0.06964)\end{array}$ & $\begin{array}{c}0.27646 \\
(0.20493)\end{array}$ & $\begin{array}{c}0.06101 \\
(0.10893)\end{array}$ \\
\hline Rent Guarantee & $\begin{array}{l}0.09648^{* * *} \\
(0.03034)\end{array}$ & $\begin{array}{r}0.07764^{*} \\
(0.04150)\end{array}$ & $\begin{array}{l}0.18228^{* * *} \\
(0.03988)\end{array}$ \\
\hline Additional Joint Property & $\begin{array}{l}0.00479^{* * *} \\
(0.00140)\end{array}$ & $\begin{array}{l}0.01009^{* *} \\
(0.00417)\end{array}$ & $\begin{array}{l}0.00428^{* * *} \\
(0.00145)\end{array}$ \\
\hline
\end{tabular}


Tab. A1. Results for Baseline Models (IV-V)

\begin{tabular}{|c|c|c|c|}
\hline & $\begin{array}{c}(1) \\
\log (\text { Price })\end{array}$ & $\begin{array}{c}(2) \\
\text { Log(Price) }\end{array}$ & $\begin{array}{c}(3) \\
\text { Log(Price) }\end{array}$ \\
\hline Predominant Building Structure is & 0.01509 & & \\
\hline Prefabricated Housing Post-War & $(0.02481)$ & & \\
\hline Predominant Building Structure is & -0.00101 & & \\
\hline Low Density Wilhelminian Style & $(0.02575)$ & & \\
\hline Predominant Building Structure is & 0.03428 & & \\
\hline \multicolumn{4}{|c|}{ High Density Wil. Style with Modifications (0.02691) } \\
\hline \multirow{2}{*}{$\begin{array}{l}\text { Predominant Building Structure is } \\
\text { High Density Wil. Style }\end{array}$} & 0.01948 & & \\
\hline & $(0.02448)$ & & \\
\hline Predominant Building Structure is & $0.13216^{* * *}$ & & \\
\hline Post-War Villas & $(0.04203)$ & & \\
\hline \multirow{2}{*}{$\begin{array}{l}\text { Predominant Building Structure is } \\
\text { Low Density Early } 20^{\text {th }} \text { Cent. Detached }\end{array}$} & 0.02784 & & \\
\hline & $(0.03170)$ & & \\
\hline \multirow{2}{*}{$\begin{array}{l}\text { Predominant Building Structure is } \\
\text { Low Density } 1990^{\text {th }}\end{array}$} & $-0.11987^{* *}$ & & \\
\hline & $(0.04880)$ & & \\
\hline \multirow{2}{*}{$\begin{array}{l}\text { Predominant Building Structure is } \\
\text { High Density Post War }\end{array}$} & 0.01126 & & \\
\hline & $(0.04020)$ & & \\
\hline Predominant Building Structure is & $0.07955^{* *}$ & & \\
\hline \multirow{2}{*}{ Low Density Post War } & $(0.03676)$ & & \\
\hline & $0.12020^{* * *}$ & & \\
\hline $\begin{array}{l}\text { Predominant Building Structure is } \\
\text { Village-like }\end{array}$ & $(0.03633)$ & & \\
\hline & 0.01529 & & \\
\hline Block Development 1920s and 1930s & $0.02759)$ & & \\
\hline Predominant Building Structure is & -0.07404 & & \\
\hline Prefabricated 1980s and 1990s & $(0.06903)$ & & \\
\hline Predominant Building Structure is & -0.13539 & & \\
\hline High Density 1990s & $(0.10427)$ & & \\
\hline \multirow[t]{2}{*}{ Shopping Potentiality $(10,000 \mathrm{sqm})$} & $0.00923^{* *}$ & & \\
\hline & $(0.00426)$ & & \\
\hline \multirow[t]{2}{*}{ Water Potentiality $(10,000$ sqm) } & 0.00006 & & \\
\hline & $(0.00087)$ & & \\
\hline \multirow[t]{2}{*}{ Green Potentiality $(10,000$ sqm $)$} & $-0.00075^{* *}$ & & \\
\hline & $(0.00034)$ & & \\
\hline \multirow[t]{2}{*}{ Relative School Potentiality } & 4.23956 & & \\
\hline & (3.01713) & & \\
\hline \multirow[t]{2}{*}{ Min. Distance to CBD West and East $(\mathrm{km})$} & $-0.02191^{* * *}$ & & \\
\hline & 0.00297 & & \\
\hline \multirow{2}{*}{ Rail Employment Potentiality $(10,000)$} & -0.00036 & & \\
\hline & $(0.01145)$ & & \\
\hline \multirow{2}{*}{$\begin{array}{l}\text { Employment Potentiality }(10,000) \\
\text { Walking Speed }\end{array}$} & 0.01326 & & \\
\hline & $(0.01487)$ & & \\
\hline \multirow[t]{2}{*}{ Population Density (Inhabitants/sqkm) } & $-0.00000^{* *}$ & & \\
\hline & $(0.00000)$ & & \\
\hline \multirow[t]{2}{*}{ Proportion Pop. under 6 Years Old (\%) } & -0.00246 & & \\
\hline & $(0.00286)$ & & \\
\hline
\end{tabular}


Tab. A1. Results for Baseline Models (V-V)

\begin{tabular}{llcc}
\hline \hline & $\begin{array}{c}(1) \\
\text { Log(Price) }\end{array}$ & $\begin{array}{c}(2) \\
\log (\text { Price })\end{array}$ & $\begin{array}{c}(3) \\
\text { Log(Price) }\end{array}$ \\
\hline Proportion Pop. 6 - 15 Years Old (\%) & -0.00209 & & \\
& $(0.00206)$ & & \\
Proportion Pop. 15 - 18 Years Old (\%) & $-0.00724^{* * *}$ & & \\
& $(0.00204)$ & & \\
Proportion Pop. 18 - 27 Years Old (\%) & -0.00039 & & \\
& $(0.00143)$ & & \\
Proportion Pop. 65 Years and Older (\%) & -0.00080 & & \\
& $(0.00094)$ & & \\
Proportion Foreign Population & $-0.00336^{* * *}$ & & \\
& $(0.00088)$ & & \\
Automobile Registrations per Capita & $0.00037^{* * *}$ & & \\
& $(0.00006)$ & & 5769 \\
Spatial Lag & Yes & & \\
Fixed Effects & & & \\
Observations & 5720 & 5769 & \\
R squared & 0.7900 & 0.8977 & 0.7860 \\
\hline \hline
\end{tabular}

Notes: Endogenous Variable is log of sales prices in all models. All models include daily time trend and monthly dummy variables. Spatial lag is a spatial autoregressive term representing the distance-weighted average of sales price per square meter of the three nearest condominium transactions, converted to a logarithm. Standard errors are clustered on statistical blocks in models (1) and (2) and traffic cells in model (3). Standard errors (in parenthesis) are heteroscedasticity robust. ${ }^{*}$ denotes significance at the $10 \%$ level; ${ }^{* *}$ denotes significance at the $5 \%$ level; ${ }^{* * *}$ denotes significance at the $1 \%$ level.

Tab. A2. Results for Extended Models (Traffic Cell Fixed Effects)

\begin{tabular}{|c|c|c|c|c|}
\hline & $\begin{array}{c}\text { (1) } \\
\log (\text { Price) }\end{array}$ & $\begin{array}{c}\text { (2) } \\
\log \text { (Price) }\end{array}$ & $\begin{array}{c}(3) \\
\log (\text { Price) }\end{array}$ & $\begin{array}{c}\text { (4) } \\
\log (\text { Price) }\end{array}$ \\
\hline Monument & $\begin{array}{l}-0.02213 \\
(0.02953)\end{array}$ & & & $\begin{array}{l}-0.02927 \\
(0.02925)\end{array}$ \\
\hline Distance to Monument & & $\begin{array}{c}0.03902 \\
(0.11415)\end{array}$ & & \\
\hline Heritage Potentiality & & & $\begin{array}{l}0.01109^{* * *} \\
(0.00510)\end{array}$ & $\begin{array}{l}0.01165^{* * *} \\
(0.00512)\end{array}$ \\
\hline $\begin{array}{l}\text { Spatial Lag } \\
\text { Fixed Effects }\end{array}$ & Traffic Cells & Traffic Cells & Traffic Cells & Traffic Cells \\
\hline Observations & 5769 & 5324 & 5769 & 5720 \\
\hline R squared & 0.7860 & 0.7877 & 0.7870 & 0.7905 \\
\hline
\end{tabular}

Notes: Variables are defined as in Table 1. The basic model is model (3) of Table A1. To save space results are presented for heritage variables only. Robust standard errors (in parenthesis) are clustered on traffic cells. ${ }^{*}$ denotes significance at the $10 \%$ level; ${ }^{* *}$ denotes significance at the $5 \%$ level; ${ }^{* * *}$ denotes significance at the $1 \%$ level. 


\section{Literature}

AHLFELDT, G. M. (2007a). If Alonso Was Right: Accessibility as Determinant for Attractiveness of Urban Location. Hamburg Contemporary Economic Discussions, 12.

AHLFELDT, G. M. (2007b). A New Central Station for a Unified City. Predicting Impact on Property Prices for Urban Railway Network Extensions. Hamburg Contemporary Economic Discussions, 13.

AHLFELDT, G. M., \& MAENNIG, W. (2007a). Assessing External Effects of City Airports: Land Values in Berlin. Hamburg Contemporary Economic Discussions, 11.

AHLFELDT, G. M., \& MAENNIG, W. (2007b). Impact of Sports Arenas on Land Values: Evidence from Berlin. International Association of Sports Economists Working Papers, 703.

ALONSO, W. (1964). Location and Land Use: Toward a General Theory of Land Rent. Cambridge, Massachusetts: Harvard University Press.

ANAS, A., \& KIM, I. (1996). General Equilibrium Models of Polycentric Urban Land Use with Endogenous Congestion and Job Agglomeration. Journal of Urban Economics, 40(2), 232-256.

ASABERE, P. K., HACHEY, G., \& GRUBAUGH, S. (1989). Architecture, Historic Zoning, and the Value of Homes. Journal of Real Estate Finance and Economics, 2(3), 181-195.

BENHAMOU, F. (2004). Who Owns Cultural Goods? The Case of Built Heritage. In V. A. GINSBURGH (Ed.), Economics of Art and Culture: Invited Papers at the 12th International Conference of the Association of Cultural Economics International; 187-202; Contributions to Economic Analysis, Vol. 260. Amsterdam; London and New York: Elsevier.

BOWES, D. R., \& IHLANFELDT, K. R. (2001). Identifying the Impacts of Rail Transit Stations on Residential Property Values. Journal of Urban Economics, 50(1), 1-25.

BRUECKNER, J. K., THISSE, J.-F., \& ZENOU, Y. (1999). Why Is Central Paris Rich and Downtown Detroit Poor? An Amenity-Based Theory. European Economic Review, 43(1), 91-107.

CAN, A., \& MEGBOLUGBE, I. (1997). Spatial Dependence and House Price Index Construction. Journal of Real Estate Finance and Economics, 14(2), 203-222.

CAROLL, T. M., CLAURETIE, T. M., \& JENSEN, J. (1996). Living Next to Godliness: Residential Property Values and Churches. Journal of Real Estate Finance and Economics, 12(3), 319-330.

CHESHIRE, P. C., \& SHEPPARD, S. (1995). On the Price of Land and the Value of Amenities. Economica, 62(246), 247-267.

COLWELL, P. F., DEHRING, C. A., \& LASH, N. A. (2000). The Effect of Group Homes on Neighborhood Property Values. Land Economics, 76(4), 615-637.

COMMITTEE OF VALUATION EXPERTS IN BERLIN. (2007). Compilation of Purchasing Price Data. Berlin.

CRAFTS, N. (2005). Market Potential in British Regions, 1871-1931. Regional Studies, 39(9), 1159-1166. 
CREIGH-TYTE, S. W. (1998). The Built Heritage in England: The History and Development of Government Policy. Cultural Trends, 32.

CREIGH-TYTE, S. W. (2000). The Built Heritage: Some British Experience. Recherches Economiques de Louvain, 66(2), 213-229.

DEHRING, C. A., DEPKEN, C. A., \& WARD, M. R. (2007). The Impact of Stadium Announcements on Residential Property Values: Evidence from a Natural Experiment in Dallas-Fort Worth. Contemporary Economic Policy, 25(4), 627638.

DEODHAR, V. (2004). Does the Housing Market Value Heritage? Some Empirical Evidence. Macquarie Economics Research Papers, 403.

DOWNES, T. A., \& ZABEL, J. E. (2002). The Impact of School Characteristics on House Prices: Chicago 1987-1991. Journal of Urban Economics, 52(1), 1.

DUBIN, R. A., \& SUNG, C.-H. (1990). Specification of Hedonic Regressions: NonNested Tests on Measures of Neighborhood Quality. Journal of Urban Economics, 27(1), 97-110.

ELKINS, T. H., \& HOFMEISTER, B. (1988). Berlin: The Spatial Structure of a Divided City. London: Methuen.

ELLEN, I. G., SCHILL, M. H., SUSIN, S., \& SCHWARTZ, A. E. (2001). Building Homes, Reviving Neighbourhoods: Spillovers from Subsidized Construction of Owner-Occupied Housing in New York City. Journal of Housing Research, 12(2), 185-216.

EPPLI, M. J., \& SHILLING, J. D. (1996). How Critical Is a Good Location to a Regional Shopping Center? Journal of Real Estate Research, 12(3), 459.

FORD, D. A. (1989). The Effect of Historic District Designation on Single-Family Home Prices. American Real Estate and Urban Economics Association Journal, 17(3), 353-362.

GALSTER, G., TATIAN, P., \& PETTIT, K. (2004). Supportive Housing and Neighborhood Property Value Externalities. Land Economics, 80(1), 33-54.

GARREAU, J. (1991). Edge City: Life on the New Frontier. New York: Doubleday.

GATZLAFF, D. H., \& SMITH, M. T. (1993). The Impact of the Miami Metrorail on the Value of Residences near Station Locations. Land Economics, 69(1), 54-66.

GIULIANO, G., \& SMALL, K. A. (1991). Subcenters in the Los Angeles Region. Regional Science and Urban Economics, 21(2), 163-182.

HALVORSEN, R., \& PALMOUIST, R. (1980). The Interpretation of Dummy Variables in Semilogarithmic Equations. American Economic Review, 70(3), 474-475.

HARRIS, C. D. (1954). The Market as a Factor in the Localization of Industry in the United States. Annals of the Association of American Geographers, 44(4), 315-348.

HEIKKILA, E., GORDON, P., KIM, J. I., PEISER, R. B., RICHARDSON, H. W., \& DALEJOHNSON, D. (1989). What Happened to the Cbd-Distance Gradient?: Land Values in a Policentric City. Environment and Planning, 21(2), 221-232.

ISAKSON, H. R. (1997). An Empirical Analysis of the Determinants of the Value of Vacant Land. Journal of Real Estate Research, 13(2), 103-114.

JORDAAN, A. C., DROST, B. E., \& MAKGATA, M. A. (2004). Land Value as a Function of Distance from the Cbd : The Case of the Eastern Suburbs of Pretoria. South African Journal of Economic and Management Sciences, 7(3), 532541. 
KEEBLE, D., OWENS, P. L., \& THOMPSON, C. (1982). Regional Accessibility and Economic Potential in the European Community. Regional Studies, 16(6), 419431.

LUCAS, R. E., JR., \& ROSSI-HANSBERG, E. (2002). On the Internal Structure of Cities. Econometrica, 70(4), 1445-1476.

MCDONALD, J. F. (1987). The Identification of Urban Employment Subcenters. Journal of Urban Economics, 21(2), 242-258.

MILLS, E. S., \& SIMENAUER, R. (1996). New Hedonic Estimates of Regional Constant Quality House Prices. Journal of Urban Economics, 39(2), 209-215.

MITCHELL, D. M. (2000). School Quality and Housing Values. Journal of Economics, 26(1), 53-68.

MUELLBAUER, J. (1974). Household Production Theory, Quality, and The "Hedonic Technique". American Economic Review, 64(5), 977-994.

MUNNEKE, H. J., \& SLADE, B. A. (2001). A Metropolitan Transaction-Based Commercial Price Index: A Time-Varying Parameter Approach. Real Estate Economics, 29(1), 55-85.

PENFOLD, V. (1994). Heritage Controls and Property Values: A Study of Four Sydney Conservation Areas. University of New South Wales.

ROSEN, S. (1974). Hedonic Prices and Implicit Markets: Product Differentiation in Pure Competition. Journal of Political Economy, 82(1), 34-55.

SCHAEFFER, P. V., \& MILLERICK, C. A. (1991). The Impact of Historic District Designation on Property Values: An Empirical Study. Economic Development Quarterly, 5(4), 301-312.

SENATSVERWALTUNG FÜR STADTENTWICKLUNG BERLIN. (2006). Urban and Environmental Information System. Berlin.

SENATSVERWALTUNG FÜR WIRTSCHAFT ARBEIT UND FRAUEN. (2004). Zentrenatlas Wirtschaftsstandort Berlin (2. ed.). Berlin: Regioverlag.

SHIPLEY, R. (2000). Heritage Designation and Property Values: Is There an Effect?. The International Journal of Heritage Studies, 6(1), 83-100.

SIRMANS, G. S., MACPHERSON, D. A., \& ZIETZ, E. N. (2005). The Composition of Hedonic Pricing Models. Journal of Real Estate Literature, 13(1), 3-43.

THÜNEN, J. H. V. (1826). Der Isolierte Staat in Beziehung Auf Landwirtschaft Und Nationalökonomie, Oder Untersuchungen Über Den Einfluss, Den Die Getreidepreise, Der Reichtum Des Bodens Und Die Abgaben Auf Ackerbau Ausüben. Hamburg: Perthes.

TU, C. C. (2005). How Does a New Sports Stadium Affect Housing Values? The Case of Fedex Field. Land Economics, 81(3), 379-395.

WHEATON, W. C. (1982). Urban Residential Growth under Perfect Foresight. Journal of Urban Economics, 12(1), 1-21. 


\section{Hamburg Contemporary Economic Discussions}

(Download: http://www.uni-hamburg.de/economicpolicy/discussions.html)

01/2005 FEDDERSEN, A. / MAENNIG, W.: Trends in Competitive Balance: Is there Evidence for Growing Imbalance in Professional Sport Leagues?, January 2005.

02/2005 SIEVERS, T.: Information-driven Clustering - An Alternative to the Knowledge Spillover Story, February 2005.

03/2005 SIEVERS, T.: A Vector-based Approach to Modeling Knowledge in Economics, February 2005.

04/2005 BUETTNER, N. / MAENNIG, W. / MENSSEN, M.: Zur Ableitung einfacher Multiplikatoren für die Planung von Infrastrukturkosten anhand der Aufwendungen für Sportstätten - eine Untersuchung anhand der Fußball-WM 2006, May 2005.

01/2006 FEDDERSEN, A.: Economic Consequences of the UEFA Champions League for National Championships - The Case of Germany, May 2006.

02/2006 FEDDERSEN, A.: Measuring Between-season Competitive Balance with Markov Chains, July 2006.

03/2006 FEDDERSEN, A. / VOEPEL, H.: Staatliche Hilfen für Profifußballclubs in finanziellen Notlagen? - Die Kommunen im Konflikt zwischen Imageeffekten und Moral-Hazard-Problemen, September 2006.

04/2006 MAENNIG, W. / SCHWARTHOFF, F.: Stadium Architecture and Regional Economic Development: International Experience and the Plans of Durban, October 2006. 


\section{Hamburg Contemporary Economic Discussions}

(Download: http://www.uni-hamburg.de/economicpolicy/discussions.html)

01

02

03

04

05

06

07

08

09

10

11

12

13

AHLFELDT, G. I MAENNIG, W.: The Role of Architecture on Urban Revitalization: The Case of "Olympic Arenas" in Berlin-Prenzlauer Berg, 2007.

FEDDERSEN, A. / MAENNIG, W. / ZIMMERMANN, P.: How to Win the Olympic Games - The Empirics of Key Success Factors of Olympic Bids, 2007.

AHLFELDT, G. / MAENNIG, W.: The Impact of Sports Arenas on Locational Attractivity: Evidence from Berlin, 2007.

DU PLESSIS, S. I MAENNIG, W.: World Cup 2010: South African Economic Perspectives and Policy Challenges Informed by the Experience of Germany 2006, 2007.

HEYNE, M. / MAENNIG, W. / SUESSMUTH, B.: Mega-sporting Events as Experience Goods, 2007.

DUST, L. / MAENNIG, W.: Shrinking and Growing Metropolitan Areas - Asymmetric Real Estate Price Reactions? The Case of German Single-family Houses, 2007.

JASMAND, S. / MAENNIG, W.: Regional Income and Employment Effects of the 1972 Munich Olympic Summer Games, 2007.

HAGN, F. / MAENNIG W.: Labour Market Effects of the 2006 Soccer World Cup in Germany, 2007.

HAGN, F. / MAENNIG, W.: Employment Effects of the World Cup 1974 in Germany.

MAENNIG, W.: One Year Later: A Re-appraisal of the Economics of the 2006 Soccer World Cup, 2007.

AHLFELDT, G., MAENNIG, W.: Assessing External Effects of City Airports: Land Values in Berlin, 2007.

AHLFELDT, G.: If Alonso was Right: Accessibility as Determinant for Attractiveness of Urban Location, 2007.

AHLFELDT, G.: A New Central Station for a Unified City: Predicting Impact on Property Prices for Urban Railway Network Extension, 2007. 


\section{Hamburg Contemporary Economic Discussions}

(Download: http://www.uni-hamburg.de/economicpolicy/discussions.html)

14

15

16

17

18

19

FEDDERSEN, A. / MAENNIG, W.: Arenas vs. Multifunctional Stadia Which Do Spectators Prefer?, 2007.

AHLFELDT, G. / FEDDERSEN, A.: Geography of a Sports Metropolis, 2007.

FEDDERSEN, A. / GROETZINGER, A. / MAENNIG, W.: New Stadia and Regional Economic Development - Evidence from FIFA World Cup 2006 Stadia, 2007

AHLFELDT, G. / MAENNIG, W.: Monumental Protection: Internal and External Price Effects, 2008

MAENNIG, W. / PORSCHE, M.: Managing the Feelgood at Mega Sport Events - Contributions to an Eclectic Theory Informed by the Experience of the FIFA World Cup 2006

AHLFELDT, G.: The Train has Left the Station: Real Estate Price Effects of Mainline Realignment in Berlin 
